\title{
RESEARCH PAPER \\ POLICY IMPLICATIONS OF STAFF TURNOVER AT THE KWAME NKRUMAH UNIVERSITY OF SCIENCE AND TECHNOLOGY LIBRARY
}

\author{
K. Agyen-Gyasi \\ University Library, KNUST, Kumasi
}

\begin{abstract}
This paper examines the staff turnover rates at the Kwame Nkrumah University of Science and Technology (KNUST) Library from January 2001 to December 2009 and how it has impacted on the output of the Library. Data for the study were obtained from official files, personal observation and interviews with selected officials directly involved in the training of new library personnel. It was observed that during the period under review, 70 members of staff left the library due to resignations, retirement and termination of appointment. The rate of turnover was found to be highest among Junior Library Assistants aged between 20 and 30 years as they tended to use the Library as a spring board to improve upon their grades in order to pursue different career paths outside librarianship. Major challenges facing the Library as a result of the high staff turnover include increased workload, poor shelving and institution of night duty schedules. It is necessary that the Library administration examines its employee performance trends to know which category of staff seem at risk of leaving and to institute human resource interventions such as training programmes, job enrichment and reward schemes to improve staff retention.
\end{abstract}

Keywords: Employee turnover, staff retention, motivation, recruitment, library

\section{INTRODUCTION}

Employees are the most valuable resources in any institution since they contribute significantly towards the attainment of organizational goals. State-owned universities in Ghana are experiencing some difficulties in recruiting and retaining high calibre academic and nonacademic staff partly due to poor remuneration and unattractive conditions of service. The establishment of private universities in Ghana is also posing a big challenge in this direction since they offer better incentive packages for their staff as compared to the state funded universities.

The concept of staff turnover implies the movement of staff members across the boundary of an organisation. It occurs when workers voluntarily or involuntarily leave their jobs and must be replaced by new recruits. It is expressed as 
an annual percentage of the total workforce. Price (2001) defines staff turnover as "the ratio of the number of organizational members who have left during the period being considered divided by the average number of people in that organization during the period". According to Famularo (1972), turnover refers to "the termination of employees and the hiring of other employees to replace them". Moreover, managers frequently refer to staff turnover as the "entire process associated with filling a vacancy" (Woods, 1995). This definition is premised on the fact that each time a position is vacated, either voluntarily or involuntarily, a new employee must be hired and trained as replacement. This replacement cycle is described here as staff turnover.

Turnover could either be "avoidable or controllable" (voluntary) or "unavoidable" or "uncontrollable" (involuntary), functional or dysfunctional. Voluntary turnover is employee initiated while involuntary turnover is normally organization initiated. However, death or mandatory retirement can also be considered as part of an involuntary turnover. Functional turnover is where the employee's departure produces a benefit while dysfunctional turnover is where the employee leaving is replaced by an individual with lower output (Cascio, 1989).

Staff turnover could be caused by pull or push factors, self-induced factors as well as job performance reasons. Pull factors refer to factors that draw employees towards another organisation such as differences in salaries or pay, managerial practices, opportunities for further enhancement, kinship responsibilities as well as job stress. Push factors, on the other hand relate to factors that could lead to dissatisfaction in their present jobs to make workers seek alternative employment such as job satisfaction, the opportunity of getting higher pay elsewhere and human resource management (HRM) issues. Self-induced reasons consist of education, age, tenure and marital status while job performance factors include strong role ambiguity, role conflict, communication systems and the intention to leave (Mobley, 1982).

Turnover affects individuals, organizations, and the entire society. It allows employees to move away from a stressful situation into a different job that is more in line with their career objectives; prevents stagnation and complacency and facilitates change and innovation; generates the infusion of new ideas into the organisation and the movement into new industries and organisations (Mobley, 1982). It also affects the efficiency of the retained workforce, takes away knowledge about business processes and systems and consequently lead to a loss of productivity, increased workloads, employee replacement expenses, loss of intellectual capital, lower employee morale and interruption in quality service. Gardner (1986) cites the effects of employee turnover as productivity losses, disruption of communication structures, loss of high performers, dissatisfaction among the remaining staff, negative public relations and operational disruption.

\section{Statement of the Problem}

Staff turnover has become a serious problem in today's corporate environment because of the changing nature of the employment culture. It is now a common practise for employees to change jobs every few years, rather than grow with one company. Furthermore, the changing demographics and societal norms are affecting the labour pool, where loyalty to one's employer is no longer the status quo.

The extent to which employees are satisfied with the prevailing conditions in the workplace could account for better organizational performance and also serve as motivation for retaining them. The reason is that happy workers tend to be efficient and productive. Among the factors that help to retain employees in the workplace include: the worker's salary, working conditions, relationships with authorities and co-workers, the employee's potential for development, level of success and the rewards given due to this success and financial security (Johnson, et.al., 2000; Islam and Islam, 2011). 
The KNUST Library is noted for high staff replacement rate compared to the other academic departments in the university. Between January 1, 2001 and December 31, 2010, as many as 70 members of staff (comprising mostly Library Assistants) left the University Library system. As a place for acquiring knowledge, the library is the storehouse of information and knowledge for building society and civilization. The library's ability to fulfil its mission and deliver excellent functions and services depends to a large extent upon its employees. This is because the library and information service requires professionals with certain skills to be able to perform their duties creditably and also contribute towards the achievement of the library's mission and vision. The high staff turnover rate at KNUST Library is a cause of concern since the bulk of the library's production system is dependent upon its employees.

In this paper, turnover problems at the KNUST Library are explored with the objective of identifying the main reasons accounting for this state of affairs and the appropriate solutions the library can adopt to manage the situation.

\section{Literature Review}

Retaining librarians by preventing turnover has become one of the leading issues in academic libraries. Rogers (2003) asserts that "the profession of librarianship in general, faces a difficult time in recruiting and retaining librarians". This statement is true in the Ghanaian context. Academic libraries in Ghana find it difficult to recruit replacements for retiring librarians, and library administrators are thus faced with shrinking staff and increased workload for the remaining staff. Government budgets to universities in Ghana in general and university libraries in particular are being reduced at a rapid rate. Although the University Rationalization Committee (1988) recommended that $10 \%$ of the total university budget should go to the libraries, none of them actually receive this figure. With such budgetary problems, library administrators in Ghana should be concerned when their employees are leaving their jobs because of the possibility of permanently losing them.

Cotton and Tuttle (1986) found that there were three categories of turnover causes: external, work-related and personal. Among many others, they found employment perceptions, union presence, overall job satisfaction, satisfaction with the work itself, pay satisfaction, satisfaction with supervision, age, tenure, gender, education, number of dependants, biographical information, organisational commitment, net expectations, and behavioural intentions to be the strongest correlates that affect turnover.

Between 1974 and 1984, Allison and Sartori (1988) identified 28 factors that contribute to professional librarians' turnover at the University of Nebraska-Lincoln (UNL). The top six factors included career goals, future salary prospects, competence of supervision, decisionmaking opportunities, stimulating work and relationship with co-workers. In their view, longevity at an institution has proved to be the strongest association with employee mobility because employees with less tenure in an organisation are normally in the early stages of their career and therefore looking for other jobs that are more lucrative. Tenure in this paper refers to the length of time an employee works for a particular employer (Gale Encyclopaedia of Small Business, 2011).

Rubin (1987) found the turnover for full-time professional librarians in moderately large and large public libraries in seven Midwestern states in the United States between 1980 and 1984 to be relatively low as compared to other professions. He stated that there was no statistical difference in turnover rates among men and women, although previous turnover studies found that women left more than men. Thapisa (1991) found that "dissatisfaction with pay remained high among employees and therefore the propensity for them to terminate their employment voluntarily also remained high". 


\section{Agyen-Gyasi}

According to Adams (1963) women bore a disproportionate responsibility for raising children and caring for dependents and thus were more likely to quit their work and assume such responsibilities. Also, women were perceived as secondary income earners in the family and therefore more likely to quit their work to follow their spouses to a more lucrative position or career. In the view of Colding (2006), the two leading factors that caused turnover among librarians were career goals and future salary prospects. Porter and Steers (1973) stated that apart from lack of tenure, career goals also account for turnover because if the career goals cannot be satisfied in the present position, the individual is likely to move to where such goals could be met.

In the African situation, Moyo (1996) indicated that at the University of Zimbabwe Library, three Sub-Librarians and 13 Assistant Librarian professional staff left the institution between January 1991 and August 1993. However, by September 1993, only one of the Sub-Librarian posts had been filled through promotion and three Assistant Librarian posts were filled, after repeated advertisements in the press. He further stated that "staffing structure and job mobility, working conditions, anomalies in university salary scales, expansion of the private sector in Zimbabwe and lack of staff training programmes were the basis for this high turnover of library professional staff which adversely affected services rendered by the library".

At the Abubakar Tafawa Balewa University Library in Nigeria, Bantai and Ogunrombi (1999) found that in the 1989/90 academic year, there was an acute shortage of staff in the library when 103 of them left the services of the Library due to resignation, transfers, dismissals, vacation of posts, death etc. They observed that the high attrition rate among the junior staff was due to a lack of promotion and career advancement prospects.

Mensah and Alemna (1997) found that the high turnover rate among professional librarians at the Ghana Library Board (GLB) was due to poor leadership and personnel policies, recruitment policies, supervisory practices, grievance procedures, poor salaries and job satisfaction among others.

\section{Purpose}

The main purpose of the study is to investigate the major reasons responsible for the high turnover rate at the KNUST Library. Other specific objectives of the study are the following:

- To find out the reasons and problems associated with high turnover in the library;

- To assess the age characteristics of the employees involved;

- To determine the status of the staff involvolved;

- To assess the career enhancement opportu nities among the staff who left the library within the stated period;

- To find the statistical relationship between gender and age, reasons, status of staff involved, and career enhancement opportunities as far as the turnover rate is concerned;

- To make recommendations as to how best the problems identified could be solved.

\section{The KNUST Library}

The Kwame Nkrumah University of Science and Technology (KNUST) Library began in a prefabricated structure in 1951 with a seating capacity for 250 readers and shelving space for 100,000 volumes before moving to its present location in April 1961. An extension to the Main University Library building which started in 1979 and was completed in 1999, provides seating capacity for 1500 readers and shelving space for about 500,000 books.

The KNUST Library system is made up of the Main Library (with seven departments namely the Library Administration, Lending, Acquisitions, Cataloguing and Classification, Reference, Serials and the Electronic Information) and six College Libraries consisting of the Colleges of Agriculture and Renewable Natural 
Staff turnover rates and its implications ...

92

Resources, Architecture and Planning Art and Social Sciences, Engineering, Health Sciences and Science. The total stock in the University Library System as at the end of 2010 was about 130,000 volumes, 5,000 print journals and over 19,000 online journals and databases. Currently, staff of the library comprise of 21 professional librarians, 22 para-professionals, 68 junior library assistants, three administrative staff, one accounting officer, 21 cleaners, one technician, three tradesmen, two drivers and eight security personnel. Altogether, the workforce of the KNUST Library System is 145.

\section{Hypotheses}

The null hypotheses for the study are as follows:

$\mathrm{H}_{1}$ : There is no statistical difference between gender and age as far as staff turnover is concerned.

$\mathrm{H}_{2}$ : There is no statistical difference between gender and the reasons influencing staff turnover.

$\mathrm{H}_{3}$ : There is no statistical difference between gender and category of staff as far as turn over is concerned.

$\mathrm{H}_{4}$ : There is no statistical difference between gender and career enhancement opportunity as far as turnover goes.

\section{METHODOLOGY}

The descriptive research design with observation and interviews was used to investigate turnover rates and the major reasons responsible for turnover in the KNUST Library system between 2001 and 2010. Data were compiled by the researcher from the personal records of the staff involved, personal interviews with selected individuals in KNUST involved in the training of new staff, and a section of former employees of the KNUST Library. This was done to reduce measurement error. The data collected included personal characteristics such as age, gender, reasons for leaving the Library and other factors relevant to staff turnover. These were supplemented by secondary data from books, journals and the Internet. The standard frequency distribution and the chi squared procedure were then used to analyse the data.

\section{Population for the study}

The population studied consisted of 70 University Library staff that left between January 1, 2001 and December 31, 2010. The categories of staff identified were Professional Librarians (Senior Members), Para-professionals (those who hold at least a Certificate or Diploma in Library studies as well as those who have been promoted to the Senior staff grade after long years of service), Junior Library Assistants (those without formal training in Librarianship and have either General Certificate of Examination (GCE) Ordinary and Advanced Level or West African Senior Secondary Certificate Examination (WASSCE)) and Administrative and Accounting staff. The administrative support staff consisted of Administrative Assistants, and Accounting Assistants, Photographers, Technicians, Clerical Staff, Security personnel, Drivers and Cleaners.

\section{FINDINGS AND DISCUSSION Categories of Staff}

The total number of staff involved in turnover at the KNUST Library between January 2001 and December 2010 are analysed in this section. In all, 70 members of staff were involved.

This was made up of 62 Library staff; seven Administrative staff and one Accounting staff. In percentage terms, they represent $88.6 \%, 10 \%$ and $1.4 \%$ respectively. Out of this 70 members of staff, $39(55.7 \%)$ were males while the remaining $31(44.3 \%)$ were females indicating that more males than females left the Library within the study period as shown in Table 1 below.

\section{The Status of Staff}

Table 2 shows the status of staff involved in turnover during the period under review. From the Table, turnover involved $60(85.7 \%)$ Junior staff; 6 (8.6\%) Senior staff and 4 (5.7\%) Senior Members. The bulk of the Junior and Senior staff were Junior Library Assistants and ParaProfessionals respectively. On the other hand, 


\section{Agyen-Gyasi}

Table 1: Categories of Staff involved in Turnover, 2001-2010

\begin{tabular}{lcccccc}
\hline Category of staff & \multicolumn{2}{c}{ Males } & \multicolumn{2}{c}{ Females } & \multicolumn{2}{c}{ Total } \\
& Number & $\%$ & Number & $\%$ & Number $\%$ \\
\hline Library Staff & 31 & 44.3 & 31 & 44.3 & 62 & 88.6 \\
Administrative Staff & 7 & 10 & 0 & 0 & 7 & 10.0 \\
Accounting Staff & 1 & 1.4 & 0 & 0 & 1 & 1.4 \\
Total & $\mathbf{3 9}$ & $\mathbf{5 5 . 7}$ & $\mathbf{3 1}$ & $\mathbf{4 4 . 3}$ & $\mathbf{7 0}$ & $\mathbf{1 0 0}$ \\
\hline
\end{tabular}

Source: Author's computation using data obtained from the KNUST Library, December 2010

Table 2: Status of Staff involved in Turnover, 2001-2010

\begin{tabular}{lcccccc}
\hline Status of Staff & $\begin{array}{c}\text { Males } \\
\text { Number }\end{array}$ & $\boldsymbol{\%}$ & Number & $\boldsymbol{\%}$ & Number & \% \\
\hline Junior Staff & 33 & 47.1 & 27 & 38.6 & 60 & 85.7 \\
Senior Staff & 4 & 5.7 & 2 & 2.9 & 6 & 8.6 \\
Senior Members & 2 & 2.9 & 2 & 2.9 & 4 & 5.7 \\
Total & $\mathbf{3 9}$ & $\mathbf{5 5 . 7}$ & $\mathbf{3 1}$ & $\mathbf{4 4 . 3}$ & $\mathbf{7 0}$ & $\mathbf{1 0 0}$ \\
\hline
\end{tabular}

Source: Author's computation using data obtained from the KNUST Library, December 2010

the Senior Members were all Professional Librarians.

\footnotetext{
Age Range

In terms of age, it is observed from Table 3 that the large majority of the turnover involved 2030 year old staff. The data also shows that as many as 40 members of staff (made up of 18 males and 22 females) representing $57.1 \%$ were in the 20-30 years age group. This is followed by the 30-40 year group which formed $21.4 \%$ (i.e. the 11 males and four females) out of the total. This means a total of 55 staff representing $78.5 \%$ of the 70 staff who left were in the 20 40 year group) which contrasts sharply with the 15 or $21.4 \%$ of the population in the $40-60$ year olds who left. Furthermore, Table 3 shows that turnover involved more males than females overall.
}

It can be concluded from Table 3 that the turnover rate was highest in the 20-30 years old staff. This is consistent with the findings of studies carried out by Porter and Steers (1973), and Price (1977), which suggest that "the turnover rate reduces as workers advance in age" mainly because as workers' tenure increases, their formal benefits (such as compensation and promotion) and informal benefits (such as status) also increase. This notion reflects Hellman's (1997) view that "employees with higher tenure are less likely to leave their organization for fear of losing some benefits upon entry into new organizations".

It is also noticed that females formed the biggest component (22 or $55 \%$ ) of the turnover rate within the 20-30 year old group. The author found out from the official records made available to him and the interviews conducted 
that, the main reasons that accounted for this state of affairs was that most of them went for further studies while others married and joined their husbands outside Kumasi. However, apart from this age group, males dominated in the other groups.

\section{Reasons for Turnover}

The reasons for turnover at the KNUST Library are analysed in Table 4 below. It is observed from this Table that 39 members of staff (made
Staff turnover rates and its implications ... 94

up of 17 males and 22 females) representing $55.7 \%$ left the library during the period under review due to resignation. According to official records from the Library, majority of them were Junior Library Assistants, who resigned their post to enable them pursue further studies in fields other than librarianship.

Vacation of post was the second highest reason with eight males and four females which represents $17.1 \%$ of the 70 staff who left. On the other hand, withdrawal of appointment, death

Table 3: Age Characteristics of Staff involved in Turnover, 2001-2010

\begin{tabular}{lcrrrrrr}
\hline Age Group (Years) & \multicolumn{2}{c}{ Males } & \multicolumn{2}{c}{ Females } & \multicolumn{2}{c}{ Total } \\
& Number & \% & Number & \% & Number & \% \\
\hline \multirow{2}{*}{$0-30$} & 18 & 25.7 & 22 & 31.4 & 40 & 57.1 \\
$30-40$ & 11 & 15.8 & 4 & 5.7 & 15 & 21.4 \\
$40-50$ & 5 & 7.1 & 3 & 4.3 & 8 & 11.4 \\
$50-60$ & 5 & 7.1 & 2 & 2.9 & 7 & 10.0 \\
Total & $\mathbf{3 9}$ & $\mathbf{5 5 . 7}$ & $\mathbf{3 1}$ & $\mathbf{4 4 . 3}$ & $\mathbf{7 0}$ & $\mathbf{1 0 0}$ \\
\hline
\end{tabular}

Source: Author's computation using data obtained from the KNUST Library, December 2010

Table 4: Reasons for Turnover, 2001-2010

\begin{tabular}{lcrcrcr}
\hline Reason & $\begin{array}{c}\text { Males } \\
\text { Number }\end{array}$ & $\mathbf{\%}$ & $\begin{array}{c}\text { Females } \\
\text { Number }\end{array}$ & $\mathbf{\%}$ & $\begin{array}{c}\text { Total } \\
\text { Number }\end{array}$ & $\%$ \\
\hline \multirow{2}{*}{ Resignation } & 17 & 24.3 & 22 & 31.4 & 39 & 57.7 \\
Termination of Appointment & 4 & 5.7 & 2 & 2.9 & 6 & 8.6 \\
Death & 2 & 2.9 & 0 & 0.0 & 2 & 2.9 \\
Vacation of Post & 8 & 11.4 & 4 & 5.7 & 12 & 17.1 \\
Retirement & 6 & 8.5 & 2 & 2.9 & 8 & 11.4 \\
Withdrawal of appointment & 0 & 0.0 & 1 & 0.0 & 1 & 1.4 \\
Other & 2 & 2.9 & 0 & 0.0 & 2 & 2.9 \\
Total & $\mathbf{3 9}$ & $\mathbf{5 5 . 7}$ & $\mathbf{3 1}$ & $\mathbf{4 4 . 3}$ & $\mathbf{7 0}$ & $\mathbf{1 0 0}$ \\
\hline
\end{tabular}

Source: Author's computation using data obtained from the KNUST Library, December 2010 


\section{Agyen-Gyasi}

and other reasons formed the least proportion of $1.4 \%$ and $2.9 \%$ respectively.

It is obvious from Table 4, that turnover at the KNUST Library emanates from three factors: institutionally exogenous reasons; self-induced and naturally-induced reasons. The institutionally exogenous reasons include termination and withdrawal of appointment and retirement from active service. The self-induced reasons consist of voluntary resignation, vacation of post and transfer to other institutions outside KNUST while the naturally-induced reasons consist of death, physical injuries, emotional and mental imbalance. Resignation of appointment constituted the highest component $(57.1 \%)$ whilst withdrawal of appointment formed the least component of $1.4 \%$. It must also be noted that although males constituted the highest proportion of the entire staff who left the KNUST library, females dominated within this category among those who resigned from the library within the stated period.

\section{Career Enhancement Opportunities of the} Staff who resigned from the Library

Table 5 shows the career enhancement opportunities of the Library staff mostly Library Assistants who left the Library within the stated period. Fifty-one members of staff were involved in this category. This excludes employees who died, were dismissed, or retired from the library but only those who voluntarily left the KNUST library either due to resignation or vacation of post. It is observed from Table 5 that $33 \mathrm{em}-$ ployees $(64.7 \%)$ left to pursue higher education mostly at the university level, $4(7.8 \%)$ members of staff resigned to pursue teacher training while only $2(3.9 \%)$ left to pursue training in nursing. Out of the 33 former members of staff who left to pursue higher education, $19(57.6 \%)$ were males while $14(42.4 \%)$ were females. In all $77.4 \%$ of the Library staff who resigned went for further studies at the university, nursing or teacher training while $22.6 \%$ travelled outside the country, pursued other vocations or sought transfer to other sister universities such as the University for Development Studies.
Thus from Table 5, it could be inferred that 39 Library staff mostly Junior Library Assistants who left the Library resigned for further studies. Out of the five members of staff who left the KNUST Library system to travel outside the country, two were trained librarians (one professional librarian and one paraprofessional) while the rest were two Library Assistants and one Administrative staff. Another striking feature about this group of staff is that females were dominant ( 3 out of 5 representing 60\%).

Based on the analysis therefore, the following conclusions were drawn. The findings on demographic variables namely age and gender are consistent with the international literature. Gender was not a significant factor differentiating "movers" (employees who left the Library within the stated period) from "stayers" (those who did not leave during the stated period). This is in line with findings from other countries that show that "women have been steadily increasing their attachment to employment and their turnover behaviour increasingly resembles that of men" (Callister, 1997; Boxall et. al., (2003).

Age, on the other hand, was found to be a significant factor in turnover behaviour. According to Burgess and Rees (1998), "the average tenure levels increase with age". Life-cycle theory posits, among other things, that younger peoples' career choices are naturally more provisional. They experiment more with career choices and types of employment.

The study has identified that the 20-30 year age group use job mobility to seek better access to good training opportunities and better opportunities outside the country. It has also revealed that the Library is being used as a spring board by the Senior High school graduates who could not make it to the next level, to better their grades and eventually leave. The study has further identified that the reasons for the high employee turnover are multi-dimensional and includes the level of pay/salary, communication 


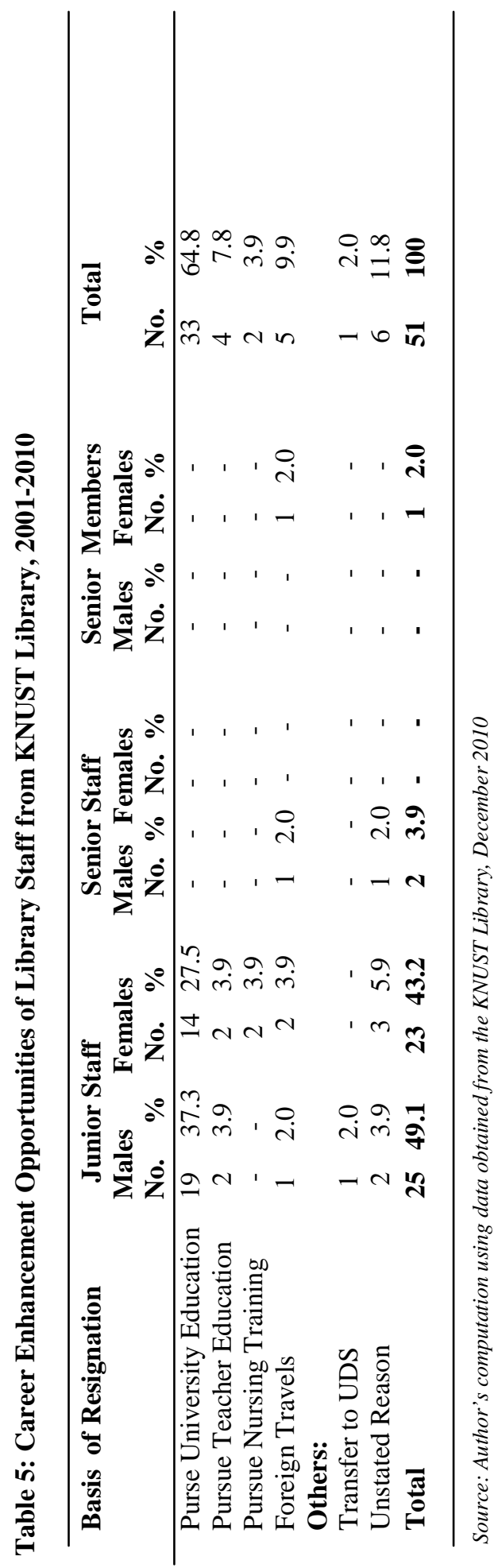

Staff turnover rates and its implications ... 96

flows, advancement opportunities, lack of recognition for a job well done, and poor relationship with management.

\section{THE CONTINGENCY TEST OF STATIS- TICAL SIGNIFICANCE}

In order to find the statistical relationships between males and females as far as the variables described above relate to staff turnover at the KNUST Library, a contingency table was used for further analysis to test whether the observed relationship between the dependent and independent variables is indeed strong or weak. A contingency table test consists of a number of rows and columns which show the relationship between two variables where the variables have been classified into mutually exclusive categories and where the data consist of frequencies (Cramer, 1998; Oluleye, 2011). It is often used to determine whether or not the two categorical variables are related to one another and to analyze important aspects of survey data namely age category, sex, income and educational levels, etc. The contingency table is assumed to follow a Chi-square distribution test statistic which is given by the formula:

$X^{2}=\sum\left(\frac{\text { fo }-\mathrm{fe}}{\mathrm{fe}}\right)^{2}$

where fo = observed frequency; fe = expected frequency

$\mathrm{fe}=\frac{\mathrm{RT} \times \mathrm{CT}}{\mathrm{N}}$

where $\mathrm{RT}=$ row total CT = column total; $\mathrm{N}=$ is the total population with $\mathrm{k}-1$ degrees of freedom (d.f.)

The null hypothesis is accepted if the computed (calculated) $\mathrm{X}^{2}$ value is less than the tabulated (critical) $\mathrm{X}^{2}$ value. On the other hand, if the tabulated (critical) $X^{2}$ value is higher than the computed (calculated) value, it is rejected and the alternative hypothesis accepted.

Causes of Turnover at the KNUST Library It is hypothesized that age, category of staff, reasons for turnover and career enhancement

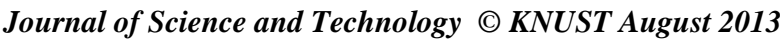




\section{Agyen-Gyasi}

opportunities of staff that left the KNUST library were responsible for the high turnover rate in the department. Chi square test was employed to test whether a statistically significant relationship exist between each of the aforementioned variables during the period under review at k-1 degrees of freedom at 0.05 level of significance. $5 \%$ level of significance was chosen for testing all the hypotheses to reflect the fact that I have $95 \%$ confidence that I am making a correct decision. The results of these statistical relationships are analysed in Tables $6,7,8$ and 9 .

\section{Gender vrs. Age}

As discussed earlier under the findings, age was found to be a significant variable influencing turnover behaviour at the KNUST Library while gender was found to be an insignificant factor. This hypothesis therefore posits that there is no statistical difference between gender and age as far as staff turnover at the KNUST Library is concerned.

The chi-square $\left(\mathrm{X}^{2}\right)$ analysis as shown in Table 6 shows that the critical chi-squared value of 7.82 is larger than the computed chi-squared value of 4.6. It is therefore, concluded that there is no statistically significant difference between age and gender as far as staff turnover at the KNUST Library is concerned. This implies that the finding of the study as indicated by the above variables is accurate.

\section{Gender vrs the Reason for Turnover}

Again, it could be inferred from the findings of the study that gender has no bearing on the reason(s) for employee turnover at the KNUST library. This hypothesis states that there is no statistical difference between gender and the reason for leaving the KNUST Library. The contingency distribution for this hypothesis is shown in Table 7 below.

From the Table, the chi-square analysis indicates that the computed $\mathrm{X}^{2}$ value is 8.9 but the critical value of $X^{2} 0.05,6=12.59$. Since the critical chi-squared value is greater than the estimated $\mathrm{X}^{2}$ value, the null hypothesis is accepted and the alternative hypothesis rejected. This means that there is no statistical relationship between gender and reason for leaving the KNUST Library. It thus implies that the finding of the study is correct.

Table 6: Contingency Table for Age of Staff and Gender Distribution, 2001-2010

\begin{tabular}{|c|c|c|c|}
\hline Age Group (Years) & Males & Females & Row Total \\
\hline $20-29$ & $\begin{array}{l}\text { fo }=18 \\
(\mathrm{fe}=22.29)\end{array}$ & $\begin{array}{l}\text { fo }=22 \\
(\mathrm{fe}=17.71)\end{array}$ & 40 \\
\hline $30-39$ & $\begin{array}{l}\text { fo }=11 \\
(\mathrm{fe}=8.36)\end{array}$ & $\begin{array}{l}\text { fo }=4 \\
(\mathrm{fe}=6.64)\end{array}$ & 15 \\
\hline $40-49$ & $\begin{array}{l}\text { fo }=5 \\
(\mathrm{fe}=4.46)\end{array}$ & $\begin{array}{l}\text { fo }=3 \\
(\mathrm{fe}=3.54)\end{array}$ & 8 \\
\hline $50-60$ & $\begin{array}{l}\text { fo }=5 \\
(\mathrm{fe}=3.90)\end{array}$ & $\begin{array}{l}\text { fo }=2 \\
(\mathrm{fe}=3.10)\end{array}$ & 7 \\
\hline Column Total & 39 & 31 & 70 \\
\hline
\end{tabular}

Source: Author's computation using data from the KNUST Library, December 2010

Critical $X^{2}=7.82, P \leq 0.05$; computed $X^{2}=4.6$; d.f. $=3$ 
Staff turnover rates and its implications ... 98

Table 7: Contingency Table for Reasons Influencing Turnover and Gender Distribution 2001-2010

\begin{tabular}{|c|c|c|c|}
\hline Reason for Turnover & Males & Females & Row Total \\
\hline Resignation & $\begin{array}{l}\text { fo }=17 \\
(\mathrm{fe}=21.73)\end{array}$ & $\begin{array}{l}\text { fo }=22 \\
(\mathrm{fe}=17.27)\end{array}$ & 39 \\
\hline Termination of Appointment & $\begin{array}{l}\text { fo }=4 \\
(\mathrm{fe}=3.34)\end{array}$ & $\begin{array}{l}\text { fo }=2 \\
(\mathrm{fe}=2.66)\end{array}$ & 6 \\
\hline Death & $\begin{array}{l}\text { fo }=2 \\
(\mathrm{fe}=1.11)\end{array}$ & $\begin{array}{l}\text { fo }=0 \\
(\mathrm{fe}=0.89)\end{array}$ & 2 \\
\hline Vacation of Post & $\begin{array}{l}\text { fo }=8 \\
(\mathrm{fe}=6.69)\end{array}$ & $\begin{array}{l}\text { fo }=4 \\
(\mathrm{fe}=5.31)\end{array}$ & 12 \\
\hline Retirement & $\begin{array}{l}\text { fo }=6 \\
(\mathrm{fe}=4.46)\end{array}$ & $\begin{array}{l}\text { fo }=2 \\
\text { (fe }=3.54)\end{array}$ & 8 \\
\hline Withdrawal of Appointment & $\begin{array}{l}\text { fo }=0 \\
(\mathrm{fe}=0.56)\end{array}$ & $\begin{array}{l}\text { fo }=1 \\
\text { (fe }=0.44)\end{array}$ & 1 \\
\hline Others & $\begin{array}{l}\text { fo }=2 \\
(\mathrm{fe}=1.11)\end{array}$ & $\begin{array}{l}\text { fo }=0 \\
\text { (fe }=0.89)\end{array}$ & 2 \\
\hline Column Total & 39 & 31 & 70 \\
\hline
\end{tabular}

Source: Author's computation using data from the KNUST Library, December 2010

Critical $X^{2}=12.59, P \leq 0.05$; computed $X^{2}=8.9$; d.f. $=6$

\section{Gender vrs the Category of Staff}

Also, from the findings of the study, it was observed that gender had no influence on the turnover intentions of the category of staff who left the KNUST Library during the period under review. The hypothesis thus postulates that "there is no statistical difference between gender and the category of staff as far as turnover at the KNUST Library is concerned". From Table 8 , the chi-square $\left(\mathrm{X}^{2}\right)$ analysis shows that the computed $\mathrm{X}^{2}$ is less than that of the critical value.

Since the critical chi-squared value of 5.99 is larger than the computed chi-squared value of 0.36 , it is concluded that there is no statistically significant difference between gender and the category of staff as far as staff turnover at KNUST Library is concerned. Hypothesis 3 is therefore accepted at $\left(\mathrm{X}^{2}=5.99, \mathrm{P} \leq 0.05\right)$ and the alternative hypothesis rejected. The implication of this conclusion is that the finding of the study in relation to the category of staff is accurate.

\section{Gender vrs Career Enhancement Opportu- nities}

Furthermore, from the study, it is concluded that gender has no influence on the career enhancement opportunities of the staff that left the KNUST Library within the stated period. The hypothesis posits that "there is no statistical difference between gender and career enhancement opportunity as far as turnover at the KNUST Library goes".

The computed $\mathrm{X}^{2}$ value from Table 9 below is 3.27 while the critical value of $X_{0.05,4}^{2}=9.49$. 


\section{Agyen-Gyasi}

It is thus concluded that since the critical $\mathrm{X}^{2}$ value is greater than the estimated $\mathrm{X}^{2}$ value, hypothesis four is accepted and the alternative hypothesis rejected. This means that there is no statistical difference between gender and the career enhancement opportunities of the staff who resigned from the KNUST Library. The implication of this decision is that the career enhancement opportunities of labour are not influenced by the gender of that particular group of labour but their future prospects.

Implications of Staff Turnover on Service Delivery at the KNUST Library

Staff turnover affects the quality of service delivery in organizations such as the KNUST Library. It affects the efficiency of the retained workforce since the volume of work to be per-

Table 8: Contingency Table of Category of Staff and Gender Distribution, 2001-2010

\begin{tabular}{lllc}
\hline Category of Staff & Males & Females & Row Total \\
\hline Junior Staff & $\begin{array}{l}\text { fo }=33 \\
(\mathrm{fe}=33.43)\end{array}$ & $\begin{array}{l}\text { fo }=27 \\
(\mathrm{fe}=26.57)\end{array}$ & 60 \\
Senior Staff & $\begin{array}{l}\text { fo }=2 \\
(\mathrm{fe}=3.33)\end{array}$ & $\begin{array}{l}(\mathrm{fe}=2.66) \\
\text { fo }=2 \\
(\mathrm{fe}=1.77)\end{array}$ & 6 \\
Senior Members & $\begin{array}{l}\text { fo }=2 \\
\text { fe }=2.23)\end{array}$ & $\mathbf{3 1}$ & 4 \\
Column Total & $\mathbf{3 9}$ & $\mathbf{7 0}$ \\
\hline
\end{tabular}

Source: Author's computation using data from the KNUST Library, December 2010

Critical $X^{2}=5.99, P \leq 0.05$; computed $X^{2}=0.36 ;$ d.f. $=2$

Table 9: Contingency Table of Career Enhancement Opportunities and Gender Distribution, 2001-2010

\begin{tabular}{|c|c|c|c|}
\hline Reason & Males & Females & Row Total \\
\hline Pursue University & fo $=16$ & fo $=12$ & 28 \\
\hline Education & $(\mathrm{fe}=15.63)$ & $(\mathrm{fe}=12.37$ & \\
\hline Teacher Training & $\begin{array}{l}\text { fo }=2 \\
(\mathrm{fe}=2.23)\end{array}$ & $\begin{array}{l}\text { fo }=2 \\
(\mathrm{fe}=1.77)\end{array}$ & 4 \\
\hline Nursing Training & $\begin{array}{l}\text { fo }=0 \\
(\mathrm{fe}=1.12)\end{array}$ & $\begin{array}{l}\text { fo }=2 \\
(\mathrm{fe}=0.88)\end{array}$ & 2 \\
\hline Travel Outside Ghana & $\begin{array}{l}\text { fo }=3 \\
(\mathrm{fe}=2.79)\end{array}$ & $\begin{array}{l}\text { fo }=2 \\
(\mathrm{fe}=2.21)\end{array}$ & 5 \\
\hline Other & $\begin{array}{l}\text { fo }=3 \\
(\mathrm{fe}=2.23)\end{array}$ & $\begin{array}{l}\text { fo }=1 \\
(\mathrm{fe}=1.77)\end{array}$ & 4 \\
\hline Column Total & 24 & 19 & 43 \\
\hline
\end{tabular}

Source: Author's computation using data obtained from the KNUST Library, December 2010

Critical $X^{2}=9.49, P \leq 0.05$; computed $X^{2}=3.27$; d.f. $=4$ 
Staff turnover rates and its implications..

formed by them would be increased. The high staff turnover at the KNUST Library has led to lower staff morale. It also suggests that employees are dissatisfied with their jobs or with the employer and thus prefer to work elsewhere. This in effect influences more workers to leave and thereby creates a very poor image for the Library.

Excellence in service delivery in any library cannot be achieved if the library staff are not of a high professional standard. Since the KNUST library faces frequent turnover it is the experienced staff who leave and this affects the quality of service rendered to users. The work in the library becomes very tiring and boring for the remaining library staff, especially if the same staff have to work in various sections for a whole day, as a result of the shortage of staff.

In addition, reduction in staff strength would lead to increased work load especially for the staff that are in charge of sections under closed access, where the materials are in high demand, and have to be fetched for readers. This implies that the staff would usually be on their feet the whole working period especially during mid and end of semester examination periods. This era of increased student numbers has exacerbated the problem. Since materials consulted by users must be re-shelved, Library Assistants are always called up to duty to locate and retrieve every consulted book and re-shelve them.

An increased staff turnover seriously affects shelving in the library. Shelving is one of the major duties of Library Assistants, both junior and senior. Books that are consulted by the users are returned to their original location by these groups of staff. Owing to increased student numbers, the number of books consulted daily by the users is large. This puts a lot of stress on the few remaining Library Assistants. There is the possibility that books which should be re-shelved might not be done well because of increased workload on the few staff that stay behind.
Another area which is affected in the Library is night duty. The University Library opens to users every evening, Mondays to Fridays. This facility allows users who would be busy during the day because of lectures or some other reason to use the library resources needed for their programme of study. Each night shift has a specific number of staff, majority of whom are Junior Library Assistants. Records available show that majority of the library assistants who do the evening duty are those who reside in communities around the University or within the University. The latter is made up of the relatives of some members of staff of KNUST. Therefore, if some employees leave, it affects the group of which that particular worker formed an integral part. It was observed that those who left were usually children or relations of other university staff who reside with them.

\section{CONCLUSION}

The study has so far shown that staff turnover is a major problem at the KNUST Library. Between January 2001 and December 2007 as many as 70 members of staff made up Professional and Para-Professional Librarians, Library Assistants, Administrative and Accounting staff left the KNUST Library either through resignation, vacation of posts, and termination of appointments or retirement from active service from the university. The turnover rate was high among Junior Library Assistants who were between the ages of 20 and 30 years. Again, the study has brought into light that nine trained librarians out of the total of 19 left the Library within the period under review, while only three Senior Members and two Senior Staff reached the mandatory retirement age of 60 years and thus went on retirement.

It was found that gender was not a significant factor differentiating those who left from those who stayed on. This is in line with findings from earlier studies done elsewhere. Age, on the other hand, was found to be a significant factor in turnover behaviour. Finally motivation for job change is multi-dimensional, meaning 


\section{Agyen-Gyasi}

that no one factor explained fully the reasons for the turnover rate at KNUST Library.

Employee turnover is very crucial in the management of human resources in any organisation. Although the University Library has data on employee performance levels, management rarely utilizes this to its advantage to manage turnover in the Library. By examining employee performance trends, management may know which category of its workers is at risk of a high turnover and thus may target human resource interventions such as training programmes, job enrichment and rewards to retain them.

\section{RECOMMENDATIONS}

Based on the findings and analysis of the results, the following recommendations are being made:

(i) There is the need to invest in the development of the staff of the KNUST Library especially the Library Assistants, through the establishment of training programmes that provide them with career development opportunities and a well defined promotions policy. This will guarantee them jog security, higher salaries and better conditions of service.

(ii) The Library should work towards harmonizing its goals and objectives with staff career needs. Staff training is one way of achieving this harmony. Such programmes could incorporate in-house training, short external courses, attachments, workshops, study tours, formal academic programmes; all within a welldefined staff development programme which give the staff the opportunity to pursue their careers, within the Library's own work programme.

(iii) Library staff should be encouraged to make suggestions when necessary and also be rewarded periodically for their contributions towards the growth of the Library.

(iv) The Library should review its recruitment policy. It is recommended that in future all po- sitions in the Library including the Junior Library Assistants grade should be advertised. This will afford people from all parts of the country who are willing to work in the Library the opportunity to do so.

(v) In future, all Junior Library Assistants employed to work in the Library should be told of available opportunities, and a programme of staff development prepared for them. This, in a way would help reduce the rate at which Junior Library Assistants leave the library.

\section{REFERENCES}

Adams, J. S. (1963). Towards an understanding of inequality, Journal of Abnormal and Social Psychology, 67: 422-436.

Allison, D. A. and Sartori, E. (1988). Professional staff turnover in academic libraries: A case study, College and Research Libraries, 42: $141-148$

Bantai, S. A. and Ogunrombi, R. C. (1999). Appraising staffing patterns in a Nigerian university library, 1981-1997, Library Career Development, 7: 77-84.

Boxall, P., Macky, K. and Rasmussen, E. (2003). Labour turnover and retention in New Zealand: the causes and consequences of leaving and staying with employers, Asia Pacific Journal of Human Resources, 41: 196 - 214 . Available online:http:// apj.sagepub.com/content/41/2/196> [Accessed 11/10/10]

Burgess, S. and Rees, H. (1998). A disaggregate analysis of the evolution of job tenure in Britain, 1975-1993, British Journal of Industrial Relations, 36: 629-655.

Callister, P. (1997). Trends in employee tenure and work scheduling patterns: a review of the empirical research evidence, Occasional paper, Department of Labour, New Zealand.

Cascio, W. (1989). Costing human resources: 
the financial impact of behaviour in organisations, Boston, MA: PWS-Kent Publishing Company.

Colding, L. K. (2006). Will they stay or will they go? predictors of academic librarian turnover, Advances in Library Administration and Organization, 23:263-280.

Cotton, J. L. and Tuttle, J. M. (1986). Employee turnover: a meta-analysis and review with implications for research, Academy and Management Review, 11: 55-70.

Cramer, D. (1998). Fundamental statistics for social research: step-by-step calculations and computer techniques using SPSS for Windows, London: Routledge.

Famularo, J. J. (1972). Handbook for modern personnel administration, New York: McGraw-Hill.

Gale Encyclopedia of Small Business (2011), Employee tenure, Available at: <http:// www.answers.com/topic/employee-tenure > [Accessed 4/4/11]

Gardner, J. E. (1986). Stabilizing the workforce: a complete guide to controlling staff turnover. Quorum Books. New York. In Moyo, Lesley M. (1996), Library staff retention strategies in the face of accelerated turnover: University of Zimbabwe Case, International. Information and Library Review, 28: 105-119

Hellman, C. H. (1997). Job satisfaction and intent to leave, Journal of Social Psychology, 137: 677-689.

Islam, M. and Islam, S. (2011). Job satisfaction of university library employees: a study of two university libraries in Bangladesh, Business Information Review, 28:184-192

Johnson, J. T., Griffeth, R.W. and Griffin, M. (2000). Factors discriminating functional and dysfunctional sales force turnover, Journal of Business \& Industrial Marketing, 15:399415. Also available: <http:// dx.doi.org/10.1108/08858620010349493> [Accessed 4/4/12]

Mensah, V. and Alemna, A. A. (1997). Staff retention in public libraries in Ghana, Library Management, 18:286-294.

Mobley, W. H. (1982). Employee turnover: causes, consequences, and control, Reading, MA: Addison-Wesley.

Moyo, L. M. (1996). Library staff retention strategies in the face of accelerated turnover: University of Zimbabwe Case, International. Information and Library Review, 28: 105119.

Oluleye, F. A. (2011). Reward economics and organisation: the issue of effectiveness, African Journal of Business Management, 5:1115-1125.

Porter, L. W. and Steers, R. M. (1973). Organizational work and personal factors in employee turnover and absenteeism, Psychological Bulletin, 80:151-176.

Price, J. L. (2001). Reflections on the determinants of voluntary turnover, International Journal of Manpower, 22: 600-624.

Rogers, M. (2003). Tackling recruitment, $\mathrm{Li}$ brary Journal, 128: 40-43

Rubin, R. (1987). A study of employee turnover of full time public librarians in moderately large and large size public libraries in seven Mid-Western States, Dissertation Abstracts International, 48 (UMI no. 8721746).

Thapisa, A. P. N. (1991). The motivation syndrome: job satisfaction through the pay nexus, International Library Review. 23: $141-158$. 
103 Agyen-Gyasi

University Rationalization Committee (1988) Woods, R. H. (1995). Managing hospitality Draft Final report. Accra: Ministry of Education and Culture, p69.

human resources, East Lansing: Educational Institute of the American Hotel and Motel Association. 